\title{
IMPLICATIONS OF BLOCKCHAIN AND TRANSPARENCY FOR BUSINESS SUSTAINABILITY: AN INTEGRATIVE REVIEW
}

\author{
HEDWIK D. GIESEL ${ }^{1}$ \\ (iD https://orcid.org/0000-0003-4970-9507 \\ FARLEY S. M. NOBRE ${ }^{1}$ \\ (iD) https://orcid.org/0000-0002-1595-8903
}

To cite this paper Giesel, H. D., \& Nobre, F. S. M. (2021). Implications of blockchain and transparency for business sustainability: An integrative review. Revista de Administração Mackenzie, 22(6), 1-30. doi:10.1590/1678-6971/eRAMD210033

Submission: Feb. 10, 2021. Acceptance: Sept. 10, 2021.

Federal University of Paraná (UFPR), Curitiba, PR, Brazil.

\section{(cc) BY




\section{ABSTRACT}

Purpose: Blockchain protocol comprises several attributes, among which transparency stands out. In this vein, the purpose of this article is to advance research on the implications of transparency (as derived from the use of blockchain) for business sustainability (BS).

Originality/value: There is continuing interest in applying blockchain for creating and improving transparency, with this latter representing a strategic asset in BS. However, despite advancing this subject, the literature still lacks studies that explain the organizational circumstances in which blockchain can enable progress on transparency in the scope of BS.

Design/method/approach: The methodology involved an integrative literature review on blockchain, transparency, and BS, and it was conducted with the support of Web of Science and Scopus to attend the research objective.

Findings: The results favored the proposal of two analytical frameworks: one refers to the concepts of blockchain and transparency presented by the academic literature, and the other to the benefits of blockchain and transparency for the economic, social, and environmental BS dimensions. Furthermore, discussions involved deducing propositions about the use of blockchain to improve transparency in the BS context. The propositions open future research directions to studies that aim to test them qualitatively or quantitatively.

\section{KEYWORDS}

Blockchain. Transparency. Business sustainability. Integrative review. Disruptive innovation. 


\section{INTRODUCTION}

There is an increasing interest in how to apply blockchain for creating and improving transparency in business organizations (Ko, Lee, \& Ryu, 2018; Reyna, Martín, Chen, Soler, \& Díaz, 2018; Tomlinson et al., 2020). An organization can expand its governance and revenue through transparency as it improves relationships and integration with stakeholders. Consumers claim that transparency stimulates commerce and is the main factor in increasing their loyalty to a company (Craig, 2018). Transparency is a multidisciplinary and constantly evolving concept related to the availability and quality of strategic information in decision-making processes at different organizational levels (Shin, Kang, \& Bae, 2020). Thus, transparency involves disseminating appropriate, timely, and accurate information (Jordan, Peek, \& Rosengren, 2000). Therefore, access to quality information is necessary for creating transparency (Albu \& Flyverbom, 2019; Bushman, Piotroski, \& Smith, 2005).

Transparency is fundamental for stakeholders' communication and integration and represents a strategic driver for creating sustainable values (Hart $\&$ Milstein, 2003). Innovative organizations that integrate stakeholders' interests and perspectives into their core businesses and reporting cycles are more likely to create high levels of transparency and succeed in their sustainability strategies (Hart \& Dowell, 2011). Thus, transparency also references an organization's increased commitment to sustainability (Fernandez-Feijoo, Romero, \& Ruiz, 2014). In business sustainability (BS), transparency is a critical asset that can involve both behavioral (implicit) and normative (explicit) processes. These processes integrate stakeholders' interests and economic, social, and environmental challenges into the organization's strategy. In addition, transparency includes the organization's accountability regarding its decisions in society (Dyllick \& Muff, 2016).

Blockchain is a technology that has gained notoriety, primarily for providing transparency (Ko et al., 2018). This disruptive technology comprises processes in which a group of users verifies transactions. This process is decentralized, distributed, immutable, and is shared with stakeholders and, therefore, it is transparent and auditable (Reyna et al., 2018). Much of the literature introduces blockchain as a technology that assists organizations in creating transparency. However, because this is a recent topic, it has not been linked (or only superficially linked) to business sustainability (Tomlinson et al., 2020). Only three papers are more clearly associated with blockchain, transparency, and sustainability, but in different contexts of BS. The first 
study employs digitization in sustainable supply chain management (Ebinger \& Omondi, 2020). The second addresses how new technologies can improve the lives of citizens in smart cities (Oliveira, Oliver, \& Ramalhinho, 2020). The third presents a blockchain-oriented technique for assessing customer satisfaction in the context of urban logistics (Tian et al., 2020). Highlighting this lack of studies, Fernández-Caramés and Fraga-Lamas (2020) suggest the need for more research on blockchain and its implications on economic, social, and environmental dimensions. Also, in this regard, Chunguang Bai and Joseph Sarkis (2020) share the need to examine the relationship between blockchain, transparency, and social sustainability.

The main argument in this research refers to the gap in the literature regarding the use of blockchain to create transparency in the context of BS and it points out the need for analyzing these three constructs in an integrative way (blockchain, transparency, and BS). Furthermore, the literature still lacks studies that explain the organizational circumstances in which blockchain can enable progress on transparency in the scope of BS. Therefore, this article seeks to answer this research question:

- How are the concepts of blockchain and transparency presented in the literature, and what are the implications of the blockchain (and its attribute, transparency) for BS?

The methodology involved an integrative literature review on blockchain, transparency, and BS, which was conducted with the support of Web of Science and Scopus to answer this research question. The results favored the proposal of two analytical frameworks. One references the concepts of blockchain and transparency presented by the academic literature, and the other the benefits of blockchain and transparency for the economic, social, and environmental BS dimensions. Furthermore, discussions involved deducing propositions about the use of blockchain to improve transparency in the BS context. The propositions open future research directions to studies that aim to test them qualitatively or quantitatively.

\section{THEORETICAL FOUNDATIONS}

This section introduces preliminary concepts of transparency, BS, and blockchain. Later, these constructs are further explored through an integrative literature review to advance the results, analysis, discussions, and propositions. 


\subsection{Transparency}

The concept of transparency may vary depending on the application area; however, it is strongly linked to the management area (Bernstein, 2017). Transparency involves disseminating timely and accurate information (Jordan et al., 2000) and the availability of appropriate information to assess stakeholders (Nicolaou \& McKnight, 2006). Moreover, it makes communication clearer or unobstructed (Potosky, 2008). Thus, scholars agree that transparency is directly related to information. More broadly, transparency is conceived as the disclosure of information which may be integral (Schnackenberg \& Tomlinson, 2016) or targeted to specific audiences according to its relevance for effective communication (Williams, 2005). Under this latter approach, transparency is considered a fundamental principle (Fernandez-Feijoo et al., 2014) and a way to promote and drive sustainability (Bai \& Sarkis, 2020) at operational and strategic levels in organizations (Fu, Shu, \& Liu, 2018). Furthermore, satisfactory and adequate transparency levels can be linked to a greater commitment to sustainability on the part of organizations to improve business reputation and legitimacy (Hart \& Milstein, 2003). Not to mention that responsiveness, learning, innovation, and performance improvement are critical links between transparency and accountability (Fernandez-Feijoo et al., 2014). Thus, access to quality information is critical for ensuring transparency and effectiveness in the organizational strategy (Albu \& Flyverbom, 2019).

\subsection{Business sustainability}

The study of sustainability in organizations was much influenced by the triple bottom line concept (Elkington, 1994), a practical approach used to guide the integration of economic, social, and environmental issues in organizations' businesses. Thus, a sustainable company contributes to solving major challenges associated with sustainable development (Dyllick \& Muff, 2016; George, Howard-Grenville, Joshi, \& Tihanyi, 2016), as it simultaneously generates economic, social, and environmental benefits (Ebinger \& Omondi, 2020; Hart \& Milstein, 2003). Therefore, a BS-driven organization integrates economic values and social and environmental issues into its core strategy to address grand challenges. In this context, organizations create values from the external environment to their internal environments, integrating sustainable development issues into their core business (Dyllick \& Muff, 2016) for building short and long-term outcomes 
(Ortiz-de-Mandojana \& Bansal, 2015). As a result, sustainable organizations innovate in a multidimensional and systemic manner while focusing on four strategic areas: 1. pollution prevention, which involves reducing costs regarding their production systems; 2 . product stewardship, which involves life cycle assessments to guarantee products' environmental sustainability and stakeholders' integration to foster transparency, connectivity with the society, and legitimacy; 3. clean technology, which involves developing future innovations markets; and 4 . bottom of the pyramid (BoP) to boost socio-economic development and environmental responsibility in a culturally sensitive way to address poverty and other sustainability issues (Hart \& Milstein, 2003; Nobre \& Morais-da-Silva, 2021). This article emphasizes the need for creating transparency in BS-driven organizations.

\subsection{Blockchain}

Blockchain - which relies on peer-to-peer networks without intermediate servers - has gained notoriety in financial transactions on a global scale in a secure, fast, inviolable, immutable, and decentralized manner (Cole, Stevenson, \& Aitken, 2019; Shin et al., 2020). The first blockchain transaction was made in 2009 by Nakamoto with Bitcoin - the first cryptocurrency (Hughes et al., 2019; Reyna et al., 2018). Initially, the blockchain used only a proof of work process in which each set or block was verified through mining before the information was stored (Fernández-Caramés \& Fraga-Lamas, 2020; Howson, 2019). Since then, various other methods of data block verification have been developed (Pop et al., 2018; Reyna et al., 2018; Sharma, Chen, \& Park, 2018).

In 2015, the proof of stake process arose from the Ethereum cryptocurrency (Reyna et al., 2018). This process is a simplified approach to the decentralized verification procedure and provides operational improvements such as savings in energy consumption (Arun Kumar, Pallath, Mohit, \& Bharath, 2020; Tomlinson et al., 2020). Furthermore, this evolution enabled the execution of smart contracts, programs that decrease the likelihood of fraud or third-party interference (Kewell, Adams, \& Parry, 2017; Pop et al., 2018). Smart contracts are self-executing contracts written in blockchain code under the terms and agreements between buyer and seller. Thus, transactions and agreements become traceable, transparent, and reliable without the need for a central authority, legal system, or external evaluation mechanism (Chapron, 2017; Mao, Hao, Wang, \& Li, 2018; Shin et al., 2020; Wang, Dabbaghjamanesh, Kavousi-Fard, \& Mehraeen, 2019). Around 2017, new 
low-cost verification methods that require less time and energy emerged, for example: Proof of Authority (PoA), in which validation occurs through access keys and identification (Kabbinale et al., 2020; Kumar et al., 2020; Toyoda, Machi, Ohtake, \& Zhang, 2020); Proof of Importance (PoI), used to determine which user is authorized to add new processes, which creates a specific hierarchy among users; and Proof of History (PoH), in which an algorithm creates transactions (Reyna et al., 2018; Sankar, Sindhu, \& Sethumadhavan, 2017). Several authors list decentralized systems, increased transparency, traceability, and immutability as key characteristics of the blockchain (Lei et al., 2017; Sharma et al., 2018; Yli-Huumo, Ko, Choi, Park, \& Smolander, 2016).

\section{METHODOLOGY: INTEGRATIVE REVIEW}

We built two analytical frameworks that bring answers to the research question: "How are the concepts of blockchain and transparency presented in the literature, and what are the implications of the blockchain (and its attribute, transparency) for BS?". One framework references the concepts of blockchain and transparency presented by the academic literature, and the other the benefits of blockchain and transparency for the economic, social, and environmental BS dimensions.

To this end, we conducted an integrative review, since this method was better suited to the purposes of this research. An integrative review is a research technique that focuses on analyzing the literature on a given topic in an integrated manner, resulting in new analytical frameworks for topics of interest (Torraco, 2016). In addition, when employed in emerging and in interdisciplinary subjects, integrative reviews tend to create concepts and models by combining perspectives from different fields of study (Botelho, Cunha, \& Macedo, 2011; Snyder, 2019).

\subsection{Analysis and selection of the articles}

The integrative literature review involved the constructs of blockchain, transparency, and sustainability. The Web of Science and Scopus databases were selected since they are widely used for research related to applied social sciences (De Bakker, Groenewegen, \& Den Hond, 2006). Thus, we searched for [blockchain AND (sustainab* AND transparen*)] in the title, abstract, and keywords fields only for peer-reviewed articles in English without a period delimitation. Additionally, we searched articles in high-impact jour- 
nals (but non-peer-reviewed) - such as MIT Sloan Management Review and Harvard Business Review. In these two journals, we found only one article within the scope of interest. The automatic and manual searches with the Web of Science and Scopus databases resulted in 87 articles and we discarded 33 duplicated articles. Finally, we selected 54 articles and reviewed their title, abstract, and keywords.

We discarded 15 articles since they were unrelated or mentioned concepts that integrate blockchain and transparency with business sustainability superficially. For example, Javed et al. (2020), Lin et al. (2017), Wong, Leong, Hew, Tan, and Ooi (2019), and Wong et al. (2020) mentioned transparency only as a feature of blockchain and did not associate it with BS.

The resulting 39 articles were entirely reviewed from abstract, introduction, concepts, results, analysis, discussions to the conclusion. At this stage, nine articles were excluded, since they were unrelated or mentioned the concepts of interest superficially. Thus, 30 articles were selected for the eligibility stage, and their entire contents were again reviewed. Another five articles were excluded for the same reasons as before.

Finally, we selected 25 articles for the stage of content analysis. We divided them into two analytical frameworks. One references the concepts of blockchain and transparency presented by the academic literature, and the other the benefits of blockchain and transparency for the economic, social, and environmental BS dimensions.

Figure 3.1.1 illustrates the Preferred Reporting Items for Systematic Reviews and Meta-Analyses (PRISMA) flow diagram (Moher, Liberati, Tetzlaff, \& Altman, 2009) for the different stages of the integrative literature review. 


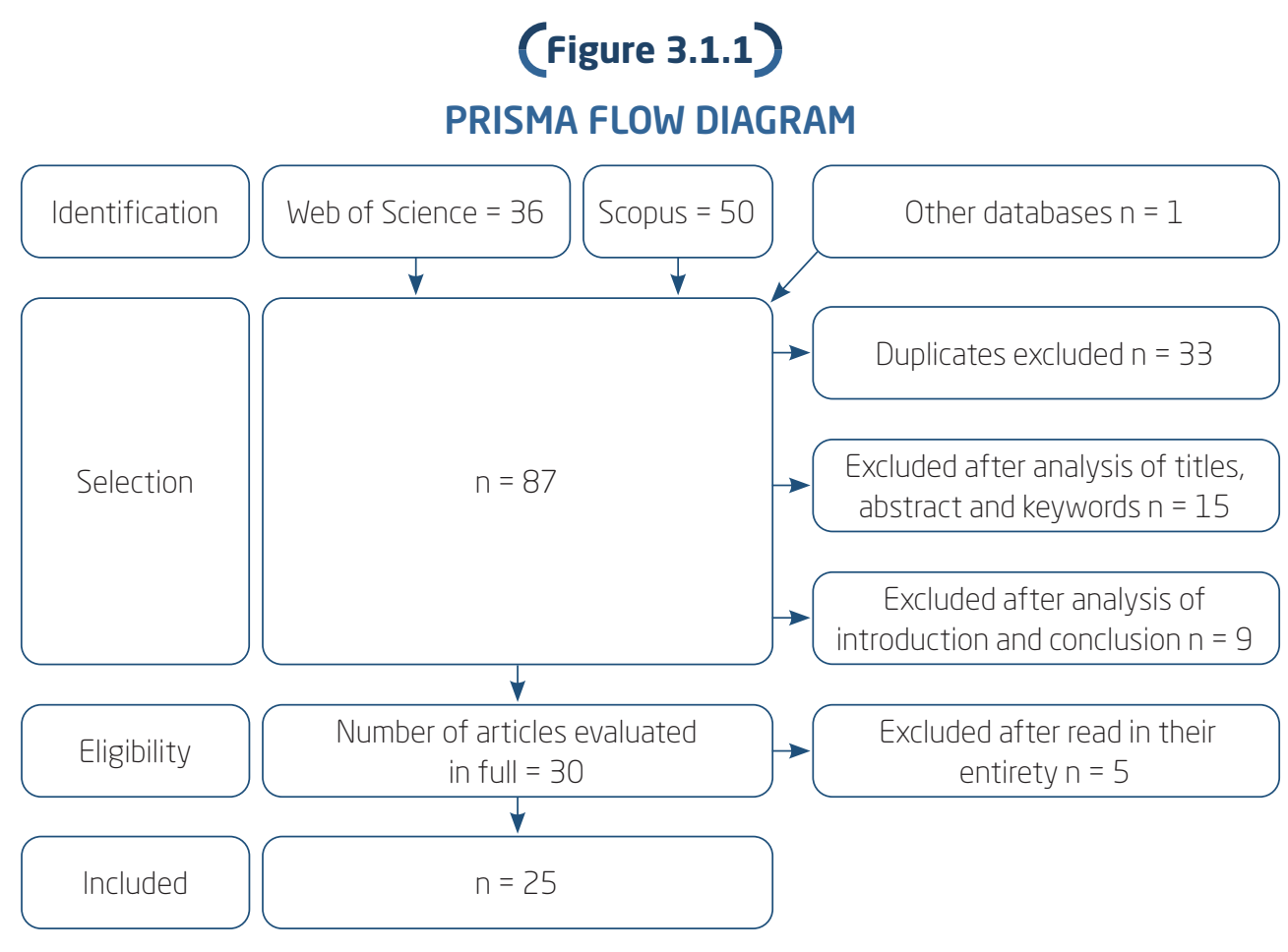

Source: Elaborated by the authors.

\subsection{Data tabulation}

Data from the 25 selected articles were organized into a spreadsheet composed of descriptive fields that included authorship, title and objective, publication year, journal, blockchain and transparency definitions, and the implications of blockchain for transparency in the economic, social, and environmental contexts. The content analysis attended to three stages (Bardin, 2011): 1. pre-analysis of the 25 selected articles; 2 . data encoding and categorization; and 3. data treatment, inference, and interpretation.

\section{RESULTS AND ANALYSIS}

\subsection{Analytical frameworks}

Figures 4.1.1 and 4.1.2 present the results of the 25 selected articles. Figure 4.1.1 presents blockchain and transparency concepts associated with 
their respective references in the third column. Figure 4.1.2 presents a classification of the blockchain's benefits for creating transparency into single and multiple BS dimensions. It also distinguishes the classification between the organization's internal and external environments.

\section{(Figure 4.1.1)}

\section{FRAMEWORK ON THE CONCEPTS OF BLOCKCHAIN AND TRANSPARENCY}

\begin{tabular}{|c|c|c|}
\hline & Concepts & References \\
\hline \multirow{3}{*}{ Blockchain } & $\begin{array}{l}\text { A distributed ledger that shares } \\
\text { information between users within } \\
\text { a chain of linked blocks. }\end{array}$ & $\begin{array}{l}\text { Fu et al. (2018), Gaur and Gaiha (2020), Howson } \\
\text { (2020), Ko et al. (2018), Fraga-Lamas and } \\
\text { Fernández-Caramés (2019), Lee, Seo, Kim, and } \\
\text { Jeong (2018), Nikolakis, John, and Krishnan (2018), } \\
\text { Oliveira et al. (2020), Saberi, Kouhizadeh, Sarkis, } \\
\text { and Shen (2019), Tian et al. (2020), Tomlinson } \\
\text { et al. (2020), Venkatesh, Kang, Wang, Zhong, and } \\
\text { Zhang (2020), Zhao et al. (2019) and Zhao, Guo, } \\
\text { and Chan (2020). }\end{array}$ \\
\hline & $\begin{array}{l}\text { A decentralized and encrypted } \\
\text { system that stores and links data } \\
\text { on each transaction users make } \\
\text { through algorithms. It may contain } \\
\text { public or private keys. }\end{array}$ & $\begin{array}{l}\text { Bai and Sarkis (2020), Ebinger and Omondi } \\
\text { (2020), Kim and Shin (2019), Kouhizadeh, Saberi, } \\
\text { and Sarkis (2021), Lahkani, Wang, Urbański, and } \\
\text { Egorova (2020), Rane, Thakker, and Kant (2020), } \\
\text { Tsolakis, Niedenzu, Simonetto, Dora, and Kumar } \\
\text { (2020), Shin et al. (2020), Tan and Sundarakani } \\
\text { (2020), and Yadav and Singh (2020). }\end{array}$ \\
\hline & $\begin{array}{l}\text { A digital and decentralized } \\
\text { database that may contain any } \\
\text { kind of information with defined } \\
\text { rules for encrypted information } \\
\text { updates. }\end{array}$ & Kamblea, Gunasekaranb, and Sharmaa (2020). \\
\hline Transparency & $\begin{array}{l}\text { It is related to the real-time } \\
\text { spread and accessibility of data by } \\
\text { all users of a system. }\end{array}$ & $\begin{array}{l}\text { Bai and Sarkis (2020), Fu et al. (2018), Howson } \\
\text { (2020), Kamblea et al. (2020) Kim and Shin } \\
\text { (2019), Ko et al. (2018), Kouhizadeh et al. (2021), } \\
\text { Fraga-Lamas and Fernández-Caramés (2019), } \\
\text { Lahkani et al. (2020), Lee et al. (2018), Nikolakis } \\
\text { et al. (2018), Rane et al. (2020), Saberi et al. } \\
\text { (2019), Tomlinson et al. (2020), Tsolakis et al. } \\
\text { (2020), Venkatesh et al. (2020), Yadav and Singh } \\
\text { (2020), Zhao et al. (2019), Zhao et al. (2020), and } \\
\text { Gaur and Gaiha (2020). }\end{array}$ \\
\hline
\end{tabular}

(continue) 


\section{(Figure 4.1 .1 (conclusion))}

\section{FRAMEWORK ON THE CONCEPTS OF BLOCKCHAIN AND TRANSPARENCY}

\begin{tabular}{lll}
\hline \multicolumn{1}{c}{ Concepts } & \multicolumn{1}{c}{ References } \\
\hline \multirow{3}{*}{ Transparency } & $\begin{array}{l}\text { It is linked to the spread of } \\
\text { relevant information that } \\
\text { supports a sustainable and } \\
\text { trustworthy relationship with } \\
\text { stakeholders. }\end{array}$ & $\begin{array}{l}\text { Ebinger and Omondi (2020), Oliveira et al. (2020), } \\
\text { Tan and Sundarakani (2020), Tian et al. (2020), } \\
\text { and Shin et al. (2020). }\end{array}$ \\
\hline
\end{tabular}

Source: Elaborated by the authors.

\section{(Figure 4.1.2)}

\section{FRAMEWORK ON THE BLOCKCHAIN'S BENEFITS FOR CREATING TRANSPARENCY IN THE BS CONTEXT}

\begin{tabular}{|c|c|c|c|c|}
\hline & Internal & External & Sector & References \\
\hline Economic & $\begin{array}{l}\text { Fraud reduction; } \\
\text { inventory and cost } \\
\text { reduction; risk mitigation; } \\
\text { improvement in quality } \\
\text { decision-making; agility } \\
\text { in payment. }\end{array}$ & $\begin{array}{l}\text { Reduction of } \\
\text { intermediaries; increased } \\
\text { transparency and trust, } \\
\text { stimulating donations } \\
\text { and credit; more } \\
\text { assertive communication } \\
\text { between stakeholders. }\end{array}$ & $\begin{array}{l}\text { Supply } \\
\text { chain, NGOs, } \\
\text { industry. }\end{array}$ & $\begin{array}{l}\text { Gaur and Gaiha } \\
\text { (2020), Ko et al. } \\
\text { (2018), Lahkani } \\
\text { et al. (2020), Kim } \\
\text { and Shin (2019), } \\
\text { Shin et al. (2020), } \\
\text { and Tan and } \\
\text { Sundarakani } \\
\text { (2020). }\end{array}$ \\
\hline Social & Human and labor rights. & $\begin{array}{l}\text { Credit for small } \\
\text { organizations; more } \\
\text { credibility when } \\
\text { managing donations. }\end{array}$ & $\begin{array}{l}\text { Supply } \\
\text { chain, NGOs. }\end{array}$ & $\begin{array}{l}\text { Lee et al. (2018) } \\
\text { and Venkatesh } \\
\text { et al. (2020). }\end{array}$ \\
\hline Environmental & $\begin{array}{l}\text { Reliable and quick sale } \\
\text { and purchase of carbon } \\
\text { credit; digital "green" } \\
\text { certificates; more } \\
\text { efficient management of } \\
\text { resources, inputs, waste, } \\
\text { and recycling materials; } \\
\text { decrease of food waste. }\end{array}$ & $\begin{array}{l}\text { Food safety; Helps the } \\
\text { circular economy; safety } \\
\text { and information to } \\
\text { stakeholders about the } \\
\text { environmental impact; } \\
\text { quality food to the } \\
\text { consumer. }\end{array}$ & $\begin{array}{l}\text { Supply } \\
\text { chain, NGOs, } \\
\text { agribusiness, } \\
\text { industry, and } \\
\text { certificates. }\end{array}$ & $\begin{array}{l}\text { Ebinger and } \\
\text { Omondi (2020), } \\
\text { Fu et al. (2018), } \\
\text { Howson (2020), } \\
\text { Kouhizadeh et al. } \\
\text { (2021), Nikolakis } \\
\text { et al. (2018), Zhao } \\
\text { et al. (2019), and } \\
\text { Zhao et al. (2020). }\end{array}$ \\
\hline Socioeconomic & $\begin{array}{l}\text { Public management with } \\
\text { more transparency. }\end{array}$ & $\begin{array}{l}\text { Public transport } \\
\text { planning. }\end{array}$ & $\begin{array}{l}\text { Supply } \\
\text { chain }\end{array}$ & $\begin{array}{l}\text { Bai and Sarkis } \\
\text { (2020) and Tian } \\
\text { et al. (2020). }\end{array}$ \\
\hline
\end{tabular}

(continue) 


\section{(Figure 4.1 .2 (conclusion))}

FRAMEWORK ON THE BLOCKCHAIN'S BENEFITS FOR CREATING TRANSPARENCY IN THE BS CONTEXT

\begin{tabular}{|c|c|c|c|c|}
\hline & Internal & External & Sector & References \\
\hline $\begin{array}{l}\text { Eco-efficiency } \\
\text { (economic and } \\
\text { environmental) }\end{array}$ & $\begin{array}{l}\text { Efficient resource } \\
\text { management; assurance } \\
\text { of input security. }\end{array}$ & $\begin{array}{l}\text { Increased transparency } \\
\text { and trust among } \\
\text { stakeholders. }\end{array}$ & $\begin{array}{l}\text { Supply } \\
\text { chain }\end{array}$ & $\begin{array}{l}\text { Kamblea et al. } \\
\text { (2020) and Rane } \\
\text { et al. (2020). }\end{array}$ \\
\hline $\begin{array}{l}\text { Socioenvironmental } \\
\text { (social and } \\
\text { environmental) }\end{array}$ & Not found. & Not found. & Not found. & Not found. \\
\hline $\begin{array}{l}\text { Sustainability } \\
\text { (economic, social, } \\
\text { and environmental) }\end{array}$ & $\begin{array}{l}\text { Efficient and transparent } \\
\text { management. }\end{array}$ & $\begin{array}{l}\text { Clear relationship with } \\
\text { stakeholders. }\end{array}$ & $\begin{array}{l}\text { Supply chain, } \\
\text { industry, } \\
\text { NGOs. }\end{array}$ & $\begin{array}{l}\text { Fraga-Lamas and } \\
\text { Fernández- } \\
\text {-Caramés (2019), } \\
\text { Oliveira et al. } \\
\text { (2020), Saberi } \\
\text { et al. (2019), } \\
\text { Tomlinson et al. } \\
\text { (2020), Tsolakis } \\
\text { et al. (2020), and } \\
\text { Yadav and Singh } \\
\text { (2020). }\end{array}$ \\
\hline
\end{tabular}

NGOs: non-governmental organizations.

\subsection{Distribution of the articles per blockchain concept}

We found three distinct concepts for blockchain with the 25 selected articles, as illustrated by Figure 4.2.1. The concepts ordered in decreasing popularity are "distributed ledger", "system that stores and/or links data", and "digital and decentralized database", which are present in 14 (56\%), ten (44\%), and one (4\%) articles, respectively. "Distributed ledger" is the most popular concept, widely used as a simple definition of complex blockchain operations. In summary, this concept describes blockchain as an operation to record encrypted data and its distributed storage (Benítez-Martínez, Hurtado-Torres, \& Romero-Frías, 2020). A "system that stores and/or links data" is a simplified concept, since it does not address distributed storage. Finally, although less common, the "digital and decentralized database" definition can be considered an appropriate concept for blockchain. 


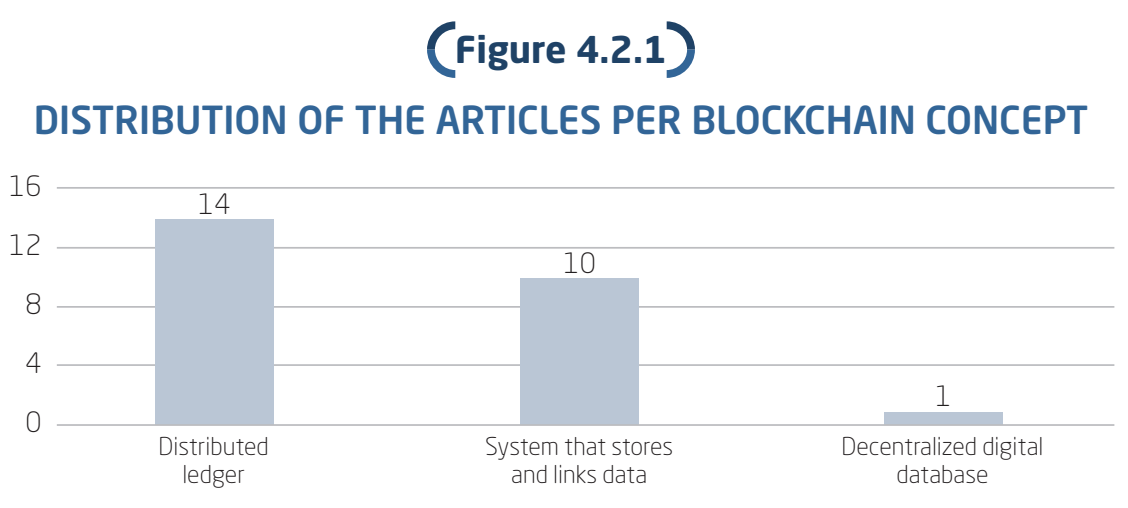

Source: Elaborated by the authors.

\subsection{Distribution of the articles per transparency's concept}

We found two main concepts for transparency in the 25 selected articles, as illustrated by Figure 4.3.1. The most popular one accounted for 20 $(80 \%)$ articles. It considers transparency as the result of dissemination and access to real-time data by all stakeholders who are system users. The second concept accounted for five (20\%) articles and linked transparency to sustainability, reliability, and integration of stakeholders. Ebinger and Omondi (2020), Tan and Sundarakani (2020), and Tian et al. (2020) suggest that high levels of transparency can assist the relationship between organizations and consumers as well as integrate stakeholders' interests into the organization's business. From this perspective, the organization can create business sustainability values in terms of its transparency, legitimacy, reputation, and connectivity with society as a whole (Hart \& Dowell, 2011; Hart \& Milstein, 2003). Shin et al. (2020) report that a more transparent environment in an NGO niche can increase predisposition to donations and philanthropy actions. 


\section{(Figure 4.3.1)}

\section{DISTRIBUTION OF THE ARTICLES PER TRANSPARENCY CONCEPT}

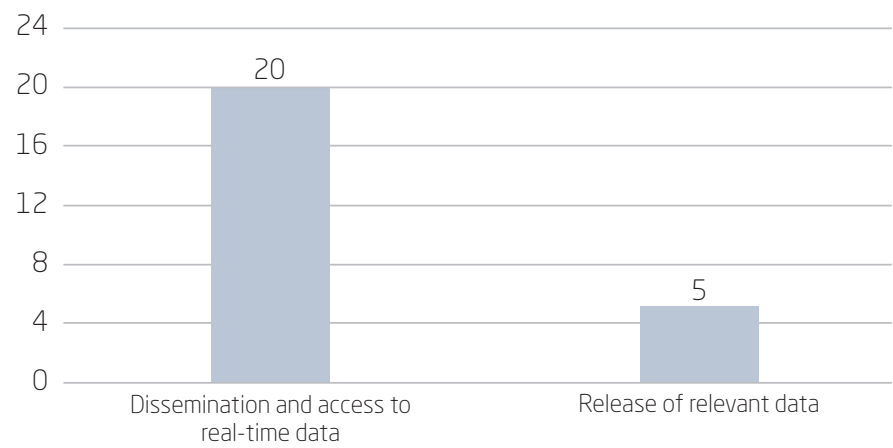

Source: Elaborated by the authors

\subsection{Distribution of the articles per BS dimension}

Figure 4.4.1 illustrates the distribution of the 25 articles per BS dimension. This distribution quantifies the associations of the blockchain (and transparency) with the single and multiple BS dimensions of Figure 4.1.2. They comprise: 1. the economic dimension as a result of the application of blockchain to improve financial processes and firm's competitiveness; 2 . the social dimension as a result of the application of blockchain to guarantee human and labor rights, philanthropy management, and improvements in public administration; 3 . the environmental dimension as a result of the application of blockchain in tracking and securing supply chains and their impacts on the natural environment; 4 . the socioeconomic dimension, which integrates economic and social values to promote greater transparency in the public sector to stop corruption, eliminates third parties and reduces costs; 5 . the eco-efficiency dimension, which involves better resources management, thereby benefiting economic and environmental issues; and 6 . the socio-environmental dimension, which integrates social and environmental issues (not found in the integrative review); and 7. sustainability, in which the three dimensions are simultaneously integrated to improve efficiency, transparency, and stakeholders' engagement. 
(Figure 4.4.1)

DISTRIBUTION OF THE ARTICLES PER BS DIMENSION

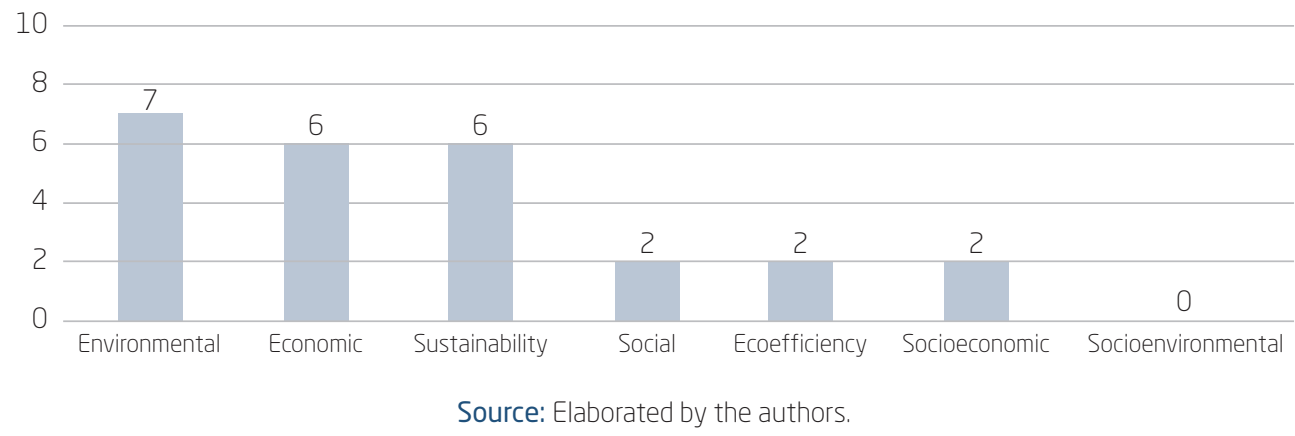

\subsection{Distribution of the articles per blockchain application sector}

Figure 4.5.1 depicts the distribution of the 25 selected articles per blockchain application sector. Most cases focused on supply chain (and value), which accounted for $15(60 \%)$ articles. We found three (12\%) articles that study the use of blockchain in NGOs and one (4\%) article for the areas of agribusiness, automotive vehicles, fashion, fishing, green (environmental) certificates, and smart cities.

(Figure 4.5.1)

\section{DISTRIBUTION OF THE ARTICLES PER BLOCKCHAIN APPLICATION SECTOR}

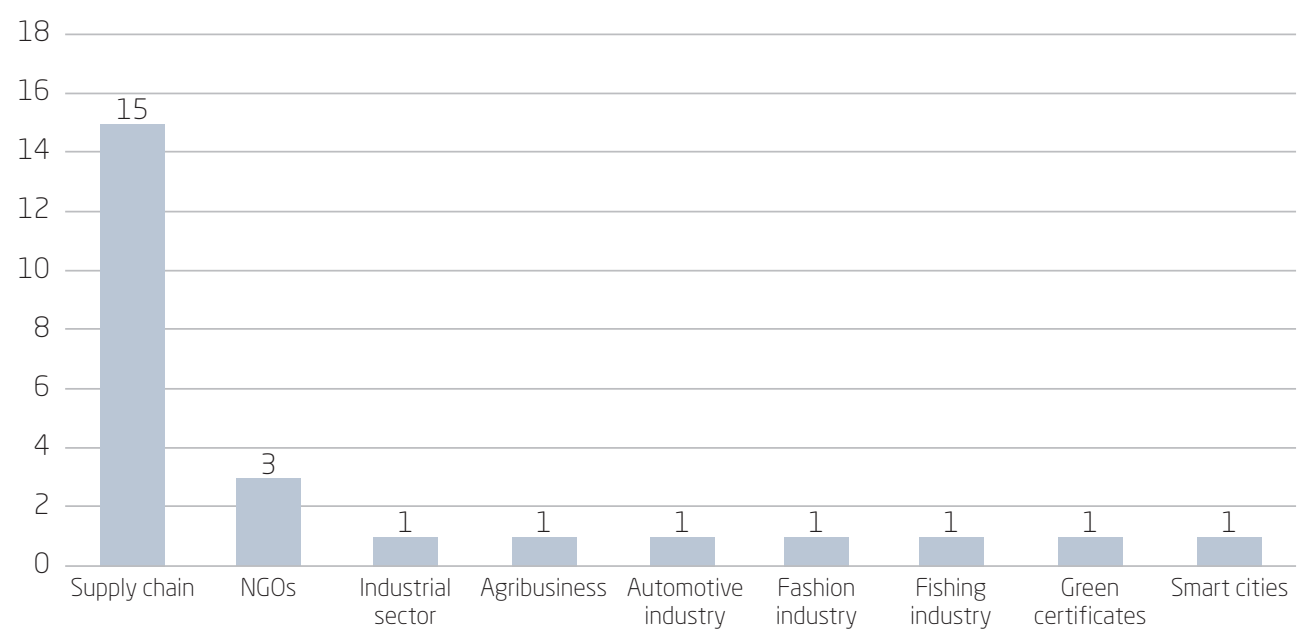

Source: Elaborated by the authors. 
Of the 25 articles, only one (4\%) explored the possible challenges and weaknesses of blockchain in-depth, whereas the other 24 (96\%) only briefly or superficially addressed them. Therefore, the following section addresses the positive and negative implications of blockchain.

\section{DISCUSSIONS AND PROPOSITIONS}

\subsection{Blockchain and transparency}

In this article, transparency is understood as a quality and a fundamental process to enhance communication and connectivity between investors, stakeholders, and the organization (Fernandez-Feijoo et al., 2014; Hart \& Milstein, 2003). Therefore, transparency is a critical asset that fosters business sustainability by integrating stakeholders' voices and interests into new opportunities and taking accountability for the economic, social, and environmental outcomes (Ebinger \& Omondi, 2020). In this context, as a blockchain attribute, transparency can be created and amplified to favor secure access to local and global data, avoiding possible fraud, fostering strategic decision-making (Fu et al., 2018). Indeed, it also favors reducing costs and intermediators (Fraga-Lamas \& Fernández-Caramés, 2019). In the integrative review, an association was observed between the use of blockchain and operational improvements in the organization's internal and external transparency for the three main BS domains.

This implies that blockchain offers significant potential for creating and improving transparency in the organization and, thus, presents itself as a technology that can favor BS strategies. Therefore, it is deduced that:

- Proposition 1: Blockchain will favor organizations driven by business sustainability (BS) strategies inasmuch as it favors progress in their levels of transparency.

\subsection{Blockchain and transparency in the BS context}

\subsubsection{Economic dimension}

Blockchain increases the quality of organizational transparency by providing access to secure information to stakeholders who can use the technology, specifically to supply chain participants. Blockchain amplifies transparency both at the executive and supplier levels for businesses and their 
customers. Transparency encourages trust on the part of investors (Ko et al., 2018) - and donors, in cases of NGOs (Shin et al., 2020) -, which increases customer retention and economic sustainability (Tian et al., 2020). Blockchain can also be applied together with the smart contract functionality, in which self-executing contracts are drawn up with the terms agreed between the buyer and the seller. Therefore, blockchain allows transactions to be traceable, transparent, and reliable without the need for a central authority or intermediary parties (Sharma et al., 2018). These factors facilitate validation, improve performance, digitalize contract negotiation, speed up processes, allow more payment freedom (Rane et al., 2020), and improve operational efficiency by reducing transaction costs (Gaur \& Gaiha, 2020). These factors can also positively influence decision-making through the timely release of strategic information (Tan and Sundarakani, 2020), less need for intermediate auditors, and decreases in inventories (Kamble et al., 2020), waste, fraud (Fraga-Lamas \& Fernández-Caramés, 2019) and flaws (Yadav \& Singh, 2020). Blockchain can improve access to credit, as Lahkani et al. (2020) reported in the Chinese project known as Digital Guangdong. This initiative began in 2019 and resulted from a joint venture involving companies from the telecommunications and banking sectors. The objective of Digital Guangdong is to increase competitiveness between the organizations through access to financing with lower costs and higher transparency levels owing to the blockchain (Nguyen, 2016). Thus, this project positively impacts both the economic and social sustainability of organizations, since it enables the introduction of micro and small businesses into the market (Lahkani et al., 2020). After highlighting how vital blockchain is to improve transparency and BS in technologically complex industrial sectors - such as telecommunications, banking, and other industries included in Figure 4.5.1 - it is deduced that:

- Proposition 2: Blockchain will favor transparency in highly complex organizations that process financial transactions for multiple stakeholders. Therefore, blockchain will favor progress in the BS economic dimension.

\subsubsection{Environmental dimension}

The digitalization of supply chains and their transactions through blockchain, combined with other disruptive technologies, can: mitigate environmental impacts resulting from the decisions and operations of organizations (Fu et al., 2018; Nikolakis et al., 2018; Zhao et al., 2019); facilitate the purchase and sale of carbon credit (Howson, 2019; Kim \& Huh, 2020) and the 
issuance of Green Certificates that ensure secure and transparent transactions (Zhao et al., 2020); promote the control of fishing operations toward environmental and food sustainability (Chapron, 2017; Howson, 2020; Tsolakis et al., 2020); ensure better management of basic resources such as water, energy, and raw materials (Tsolakis et al., 2020; Wu \& Tran, 2018; Zhao et al., 2019); and promote food waste reduction, circular economy (Shojaei et al., 2021; Tsolakis et al., 2020), better management of waste and recycling material (Bai \& Sarkis, 2020). After highlighting the potential of blockchain for digitizing supply chains and tracking their multiple transactions, it is deduced that:

- Proposition 3: Blockchain will favor digitization and tracking of supply chains and improve transparency for their multiple transactions. Therefore, blockchain benefits the BS ecological dimension inasmuch as it facilitates the environmental management of the organizations' operations and products.

\subsubsection{Social dimension}

As mentioned, blockchain can be a credit facilitator technology for micro and small organizations, like the Chinese Digital Guangdong project, which provides easy access to credit and transparent transactions through blockchain, together with banks and telecommunications companies (Lahkani et al., 2020). Moreover, blockchain favors transparent donations with privacy to organizations, which can contribute to establishing a safe environment prone to philanthropic activities with NGOs (Lee et al., 2018). Blockchain can be applied with other disruptive innovations - such as Cyber-Physical System (CPS), Internet of Things (IoT), Big Data (BD), and artificial intelligence (AI) - to favor smart cities ${ }^{2}$ and connect public administration tasks with citizens transparently (Oliveira et al., 2020; Tsolakis et al., 2020). This will increase trust and reduce fraudulent operations and corruption (Chapron, 2017; Fraga-Lamas \& Fernández-Caramés, 2019). Blockchain can facilitate issuing digital social sustainability certificates related to human and labor rights (Tsolakis et al., 2020), such as salary, working hours and working conditions, social welfare, and equity in an organization (Venkatesh et al., 2020). The Building Blocks Project of the United Nations World Food

According to Park, Lee, and Chang (2018), smart cities are cities with a technological structure to manage problems caused by rapid urbanization and population growth with the highest efficiency and optimization of resources. 
Program is a practical and emblematic case reported by Shin et al. (2020). In such a project, blockchain is used with an iris recognition technology, thus, enabling refugees allocated in Azraq and Zaatari camps in Jordan to purchase basic supplies without documents that may be lost. This project encourages and gives credibility to a process that would otherwise be carried out through physical coupons (Shin et al., 2020).

After highlighting the potential of blockchain for certifying operations related to social sustainability, it is deduced that:

- Proposition 4: Blockchain will favor transparency in organizations that process financial transactions (between the organization and stakeholders) for donation and philanthropy. Therefore, it will benefit the BS social dimension.

Therefore, it was observed that blockchain offers potential to benefit BS-driven organizations that adopt strategies to: 1. integrate stakeholder interests and create connectivity with investors and society to improve transparency, reputation, and legitimacy; 2. tracking products' life cycles and global production chains to map environmental impacts; 3 . creating a safe environment, conducive to the culture of philanthropic activities with NGOs; and 4. disseminating information and skills between the organization and its partners in the public and private sectors for the development of (open) innovations that can generate positive impacts for solving economic, social and environmental problems.

\subsection{Recommendations for blockchain adoption}

Although blockchain is widely pointed out as a technology with great potential to benefit organizations, during the review and analysis of the 25 selected articles, we identified difficulties that may prevent a successful adoption of blockchain. This subsection presents these difficulties at four interdependent levels: operational, intra-organizational, inter-organizational, and external.

Firstly, the installation of blockchain is technically complex at the operational level, thus, greater governance of systems and data is required (Fraga-Lamas \& Fernández-Caramés, 2019). Furthermore, at this level, computer technology professionals' specific skills and knowledge are rare and indispensable (Kouhizadeh et al., 2021; Zhao et al., 2019).

Secondly, a lack of commitment from members of high organizational ranks and high financial investment in a new technology system can lead to 
failure in adopting blockchain at the intra-organizational level (Ko et al., 2018). Therefore, support from senior management is a key factor for successful blockchain implementation in organizations (Saberi et al., 2019).

Third, knowing the relationship between an organization and its stakeholders is fundamental to apply blockchain at the inter-organizational level. Therefore, it is necessary to manage the relationship between partners, demonstrate the benefits of blockchain to stakeholders, and control the interoperability between systems (Fraga-Lamas \& Fernández-Caramés, 2019) and the possible resistance to information disclosure due to transparency levels (Zhao et al., 2019). Thus, it is necessary to develop clear rules and policies for sharing information (Saberi et al., 2019).

Finally, at the external and institutional levels, some studies show that stakeholders are usually adverse, if not opposed, to blockchain application. The lack of government regulatory policies (Tomlinson et al., 2020) and the operationalization of blockchain or cryptocurrencies (Chapron, 2017; Saberi et al., 2019; Zhao et al., 2019) aggravate this situation. By highlighting the levels of challenges for the adoption of blockchain in organizations, it is deduced that:

- Proposition 5: The effective adoption of blockchain will succeed inasmuch as organizations overcome simultaneous challenges at the operational, intra-organizational, inter-organizational, and external levels.

\section{FUTURE STUDIES}

This research suggests further studies about the effects of blockchain on the BS dimensions, especially regarding the social dimension, which was less evident in the literature when compared to the others. It also recommends conducting applied research to test the adoption of blockchain in organizations and compare results with the conceptual literature. Lastly, we suggest studies on the implications of the Brazilian General Personal Data Protection Law (or Lei de Geral de Proteção de Dados Pessoais - Law no. 13.709/2018) for adopting blockchain in organizations.

\section{CONCLUSION}

The integrative review contributed to answering the main question: "How are the concepts of blockchain and transparency presented in the 
literature, and what are the implications of the blockchain (and its attribute, transparency) for BS?".

The integrative review results contributed to propose two analytical frameworks. One references the concepts of blockchain and transparency presented by the academic literature, and the other the benefits of blockchain and transparency for the economic, social, and environmental BS dimensions. It was also possible to suggest propositions that need to be tested in future empirical studies on adopting blockchain to create transparency in the BS's economic, social, and environmental contexts. Blockchain presents technological capabilities that can provide: Traceability throughout the life cycle of raw materials and products to guarantee environmental management; responsible consumption and production (Chapron, 2017; Howson, 2020; Tsolakis et al., 2020); integrity about improving donation and philanthropy (Lee et al., 2018); digitization of supply chains for better accountability to the several stakeholders that become more connected and informed and create a greater degree of trust among themselves; among other benefits.

In addition to presenting novel propositions on blockchain in creating transparency in the BS context, this research presented recommendations for the blockchain adoption at distinct organizational levels. Thus, this article contributes to a better understanding of the blockchain implications (especially its transparency attribute) for organizations driven by BS strategies.

This article found some limitations because of the reduced literature available on this new research topic.

\section{IMPLICAÇÕES DE BLOCKCHAIN E TRANSPARÊNCIA PARA A SUSTENTABILIDADE EMPRESARIAL: REVISÃO INTEGRATIVA}

\section{TESUMO}

Objetivo: O protocolo de redes blockchain engloba diversos atributos, entre os quais se destaca a transparência. Dessa forma, o objetivo deste artigo é avançar nos conhecimentos sobre as implicações da transparência, derivada do uso de blockchain, para a sustentabilidade empresarial (SE). Originalidade/valor: Há um interesse crescente na literatura sobre a utilização de blockchain como mecanismo para criação e melhoria de trans- 
parência interpretada como elemento estratégico para a sustentabilidade nas organizações empresariais. Apesar dos avanços nesse campo, ainda há necessidade de explicar as circunstâncias organizacionais em que blockchain pode promover transparência no contexto da SE.

Design/metodologia/abordagem: Para atender ao objetivo de pesquisa, realizou-se uma revisão integrativa da literatura sobre blockchain, transparência e SE, utilizando-se de recursos como Web of Science e Scopus.

Resultados: Os resultados favoreceram a proposta de dois quadros de análise: um referente a como os conceitos de blockchain e transparência vêm sendo apresentados em conjunto pela academia, e outro sobre os benefícios de blockchain e transparência para as dimensões econômica, social e ambiental da SE. As discussões possibilitaram a dedução de proposições sobre a adoção de blockchain para melhoria de transparência no contexto de SE e que poderão ser testadas em estudos futuros na forma qualitativa ou quantitativa.

\section{PALAVRAS-CHAVE}

Blockchain. Transparência. Sustentabilidade empresarial. Revisão integrativa. Inovação disruptiva.

\section{$\int$ REFERENCES}

Albu, O. B., \& Flyverbom, M. (2019). Organizational transparency: Conceptualizations, conditions, and consequences. Business and Society, 58(2), 268-297. doi:10.1177/0007650316659851

Arun Kumar, S., Pallath, R., Mohit, A., \& Bharath, K. K. (2020). Intelligent securing of the industrial IoT data based on consensus mechanism. International Journal of Advanced Science and Technology, 29(5), 3040-3052. Retrieved from http://sersc.org/journals/index.php/IJAST/article/view/ 11607

Bai, C., \& Sarkis, J. (2020). A supply chain transparency and sustainability technology appraisal model for blockchain technology. International Journal of Production Research, 58(7), 2142-2162. doi:10.1080/00207543.2019. 1708989 
Bardin, L. (2011). Análise de conteúdo. São Paulo: Edições 70.

Benítez-Martínez, F. L., Hurtado-Torres, M. V., \& Romero-Frías, E. (2020). A neural blockchain for a tokenizable e-Participation model. Neurocomputing, 423, 703-712. doi:10.1016/j.neucom.2020.03.116

Bernstein, E. S. (2017). Making transparency transparent: The evolution of observation in management theory. Academy of Management Annals, 11(1), 217-266. doi:10.5465/annals.2014.0076

Botelho, L. L. R., Cunha, C. C. de A., \& Macedo, M. (2011). O método da revisão integrativa nos estudos organizacionais. Gestão e Sociedade, 5(11), 121-136. doi:10.21171/ges.v5i11.1220

Bushman, R. M., Piotroski, J. D., \& Smith, A. J. (2003). What determines corporate transparency? SSRN Electronic Journal, 42(2), 1-53. doi:10.2139/ ssrn. 428601

Chapron, G. (2017). The environment needs cryptogovernance. Nature, 545(7655), 403-405. doi:10.1038/545403a

Cole, R., Stevenson, M., \& Aitken, J. (2019). Blockchain technology: Implications for operations and supply chain management. Supply Chain Management, 24(4), 469-483. doi:10.1108/SCM-09-2018-0309

Craig, W. (2018). 10 Things transparency can do for your company. Forbes. Retrieved from https://www.forbes.com/sites/williamcraig/2018/10/16/ 10-things-transparency-can-do-for-your-company/\#4d53204b25d0

De Bakker, F. G. A., Groenewegen, P., \& Den Hond, F. (2006). A research note on the use of bibliometrics to review the corporate social responsibility and corporate social performance literature. Business and Society, 45(1), 7-19. doi:10.1177/0007650305283092

Dyllick, T., \& Muff, K. (2016). Clarifying the meaning of sustainable business: Introducing a typology from business-as-usual to true business sustainability. Organization and Environment, 29(2), 156-174. doi:10.1177/ 1086026615575176

Ebinger, F., \& Omondi, B. (2020). Leveraging digital approaches for transparency in sustainable supply chains: A conceptual paper. Sustainability, 12(15), 1-6. doi:10.3390/su12156129

Elkington, J. (1994). Towards the sustainable corporation: Win-win-win business strategies for sustainable development. Corporate Environmental Responsibility, 36(2), 109-119. doi:10.2307/41165746 
Fernández-Caramés, T. M., \& Fraga-Lamas, P. (2020). Towards post-quantum blockchain: A review on blockchain cryptography resistant to quantum computing attacks. IEEE Access, 8, 21091-21116. doi:10.1109/ACCESS. 2020.2968985

Fernandez-Feijoo, B., Romero, S., \& Ruiz, S. (2014). Effect of stakeholders' pressure on transparency of sustainability reports within the GRI framework. Journal of Business Ethics, 122(1), 53-63. doi:10.1007/s10551-0131748-5

Fraga-Lamas, P., \& Fernández-Caramés, T. M. (2019). A review on blockchain technologies for an advanced and cyber-resilient automotive industry. IEEE Access, 7, 17578-17598. doi:10.1109/ACCESS.2019.2895302

Fu, B., Shu, Z., \& Liu, X. (2018). Blockchain enhanced emission trading framework in fashion apparel manufacturing industry. Sustainability, 10(4), 1-19. doi:10.3390/su10041105

Gaur, V., \& Gaiha, A. (2020). Building a transparent supply chain. Harvard Business Review, 98(3), 94-103. Retrieved from https://hbr.org/2020/05/ building-a-transparent-supply-chain

George, G., Howard-Grenville, J., Joshi, A., \& Tihanyi, L. (2016). Understanding and tackling societal grand challenges through management research. Academy of Management Journal, 59(6), 1880-1895. https://doi. org/10.5465/amj.2016.4007

Hart, S. L., \& Dowell, G. (2011). Invited editorial: A natural-resource-based view of the firm: Fifteen years after. Journal of Management, 37(5), 1464-1479. doi:10.1177/0149206310390219

Hart, S. L., \& Milstein, M. B. (2003). Creating sustainable value. Academy of Management Executive, 17(2), 56-69. doi:10.5465/ame.2003.10025194

Howson, P. (2019). Tackling climate change with blockchain. Nature, 9, 644-645. doi:10.1038/s41558-019-0567-9.

Howson, P. (2020). Building trust and equity in marine conservation and fisheries supply chain management with blockchain. Marine Policy, 115, 103873. doi:10.1016/j.marpol.2020.103873

Hughes, L., Dwivedi, Y. K., Misra, S. K., Rana, N. P., Raghavan, V., \& Akella, V. (2019). Blockchain research, practice and policy: Applications, benefits, limitations, emerging research themes and research agenda. International Journal of Information Management, 49, 114-129. doi:10.1016/j.ijinfomgt. 2019.02.005 
Huh, J. H., \& Kim, S. K. (2019). The blockchain consensus algorithm for viable management of new and renewable energies. Sustainability, 11(11), 1-26 doi:10.3390/su11113184

Javed, M. U., Javaid, N., Aldegheishem, A., Alrajeh, N., Tahir, M., \& Ramzan, M. (2020). Scheduling charging of electric vehicles in a secured manner by emphasizing cost minimization using blockchain technology and IPFS. Sustainability, 12(12),1-25. doi:10.3390/su12125151

Jordan, J. S., Peek, J., \& Rosengren, E. S. (2000). The market reaction to the disclosure of supervisory actions: Implications for bank transparency. Journal of Financial Intermediation, 9(3), 298-319. doi:10.1006/jfin.2000.0292

Kabbinale, A. R., Dimogerontakis, E., Selimi, M., Ali, A., Navarro, L., Sathiaseelan, A., \& Crowcroft, J. (2020). Blockchain for economically sustainable wireless mesh networks. Concurrency Computation, 32(12), 1-18. doi:10.1002/cpe.5349

Kamble, S. S., Gunasekaran, A., \& Sharma, R. (2020). Modeling the blockchain enabled traceability in agriculture supply chain. International Journal of Information Management, 52, 1-16. doi:10.1016/j.ijinfomgt.2019.05.023

Kewell, B., Adams, R., \& Parry, G. (2017). Blockchain for good? Strategic Change, 26(5), 429-437. doi:10.1002/jsc.2143

Kim, S. K., \& Huh, J. H. (2020). Blockchain of carbon trading for UN sustainable development goals. Sustainability, 12(10), 1-10. doi:10.3390/SU 12104021

Kim, J. S., Shin, N. (2019). The impact of blockchain technology application on supply chain partnership and performance. Sustainability, 11(21), 1-17. doi:10.3390/su11216181

Ko, T., Lee, J., \& Ryu, D. (2018). Blockchain technology and manufacturing industry: Real-time transparency and cost savings. Sustainability, 10(11), 1-20. doi:10.3390/su10114274

Köhler, S., \& Pizzol, M. (2020). Technology assessment of blockchain-based technologies in the food supply chain. Journal of Cleaner Production, 269, 1-10. doi:10.1016/j.jclepro.2020.122193

Kouhizadeh, M., Saberi, S., \& Sarkis, J. (2021). Blockchain technology and the sustainable supply chain: Theoretically exploring adoption barriers. International Journal of Production Economics, 231, 107831. doi:10.1016/ j.ijpe.2020.107831

Kubilay, M. Y., Kiraz, M. S., \& Mantar, H. A. (2019). CertLedger: A new PKI model with certificate transparency based on blockchain. Computers and Security, 85, 333-352. doi:10.1016/j.cose.2019.05.013 
Kumar, G., Saha, R., Buchanan, W. J., Geetha, G., Thomas, R., Rai, M. K., Kim, T. H., \& Alazab, M. (2020). Decentralized accessibility of e-commerce products through blockchain technology. Sustainable Cities and Society, 62, 102361. doi:10.1016/j.scs.2020.102361

Lahkani, M. J., Wang, S., Urbański, M., \& Egorova, M. (2020). Sustainable B2B e-commerce and blockchain-based supply chain finance. Sustainability, 12(10), 1-14. doi:10.3390/SU12103968

Lee, J., Seo, A., Kim, Y., \& Jeong, J. (2018). Blockchain-based one-off address system to guarantee transparency and privacy for a sustainable donation environment. Sustainability, 10(12), 1-14. doi:10.3390/su10124422

Lei, A., Cruickshank, H., Cao, Y., Asuquo, P., Ogah, C. P. A., \& Sun, Z. (2017). Blockchain-based dynamic key management for heterogeneous intelligent transportation systems. IEEE Internet of Things Journal, 4(6), 1832-1843. doi:10.1109/JIOT.2017.2740569

Lin, Y. P., Petway, J. R., Anthony, J., Mukhtar, H., Liao, S. W., Chou, C. F., \& Ho, Y. F. (2017). Blockchain: The evolutionary next step for ICT e-agriculture. Environments - MDPI, 4(3), 1-13. doi:10.3390/environments4030050

Mao, D., Hao, Z., Wang, F., \& Li, H. (2018). Innovative blockchain-based approach for sustainable and credible environment in food trade: A case study in Shandong Province, China. Sustainability, 10(9), 31-49. doi:10.33 90/su10093149

Moher, D., Liberati, A., Tetzlaff, J., \& Altman, D. G. (2009). Preferred Reporting Items for Systematic Reviews and Meta-Analyses: The PRISMA statement. BMJ, 339(7716), 332-336. doi:10.1136/bmj.b2535

Naidoo, R., \& Fisher, B. 2020. Reset sustainable development goals for a pandemic world. Nature, 583, 198-201. doi:10.1038/d41586-020-01999-x

Nguyen, Q. K. (2016). Blockchain: A financial technology for future sustainable development. Proceedings of International Conference on Green Technology and Sustainable Development, 3 Kaohsiung, Taiwan. doi:10.1109/GTSD. 2016.22

Nicolaou, A. I., \& McKnight, D. H. (2006). Perceived information quality in data exchanges: Effects on risk, trust, and intention to use. Information Systems Research, 17(4), 332-351. doi:10.1287/isre.1060.0103

Nikolakis, W., John, L., \& Krishnan, H. (2018). How blockchain can shape sustainable global value chains: An Evidence, Verifiability, and Enforceability (EVE) Framework. Sustainability, 10(11), 1-16. doi:10.3390/su10 113926 
Nobre, F. S., \& Morais-da-Silva, R.L. (2021). Capabilities of bottom of the pyramid organizations. Business \& Society, 59(6), 1-42. doi:10.1177/00076 503211001826

Oliveira, T. A., Oliver, M., \& Ramalhinho, H. (2020). Challenges for connecting citizens and smart cities: ICT, e-governance and blockchain. Sustainability, 12(7), 1-21. doi:10.3390/su12072926

Ortiz-de-Mandojana, N., \& Bansal, P. (2015). The long-term benefits of organizational resilience through sustainable business practices. Strategic Management Journal, 3(8), 1615-1631. doi:10.1002/smj.2410

Park, L. W., Lee, S., \& Chang, H. (2018). A sustainable home energy prosumerchain methodology with energy tags over the blockchain. Sustainability, 10(3), 1-18. doi:10.3390/su10030658

Pop, C., Cioara, T., Antal, M., Anghel, I., Salomie, I., \& Bertoncini, M. (2018). Blockchain based decentralized management of demand response programs in smart energy grids. Sensors, 18(1), 1-9. doi:10.3390/s18010162

Potosky, D. (2008). A conceptual framework for the role of the administration medium in the personnel assessment process. Academy of Management Review, 33(3), 629-648. doi:10.5465/AMR.2008.32465704

Rane, S. B., Thakker, S. V., \& Kant, R. (2020). Stakeholders' involvement in green supply chain: A perspective of blockchain IoT-integrated architecture. Management of Environmental Quality: An International Journal, 32(6), 1166-1191. doi:10.1108/MEQ-11-2019-0248

Reyna, A., Martín, C., Chen, J., Soler, E., \& Díaz, M. (2018). On blockchain and its integration with IoT. Challenges and opportunities. Future Generation Computer Systems, 88, 173-190. doi:10.1016/j.future.2018.05.046

Saberi, S., Kouhizadeh, M., Sarkis, J., \& Shen, L. (2019). Blockchain technology and its relationships to sustainable supply chain management. International Journal of Production Research, 57(7), 2117-2135. doi:10.1080/ 00207543.2018 .1533261

Sankar, L. S., Sindhu, M., \& Sethumadhavan, M. (2017). Survey of consensus protocols on blockchain applications. International Conference on Advanced Computing and Communication Systems, 4, Coimbatore, India. doi:10.1109/ ICACCS.2017.8014672

Schnackenberg, A. K., \& Tomlinson, E. C. (2016). Organizational transparency: A new perspective on managing trust in organization-stakeholder relationships. Journal of Management, 42(7), 1784-1810. doi:10.1177/ 0149206314525202 
Sharma, P. K., Chen, M. Y., \& Park, J. H. (2018). A software defined fog node based distributed blockchain cloud architecture for IoT. IEEE Access, 6, 115-124. doi:10.1109/ACCESS.2017.2757955

Shin, E. J., Kang, H. G., \& Bae, K. (2020). A study on the sustainable development of NPOs with blockchain technology. Sustainability, 12 (15), 1-10. doi:10.3390/su12156158

Snyder, H. (2019). Literature review as a research methodology: An overview and guidelines. Journal of Business Research, 104, 333-339. doi:10.1016/ j.jbusres.2019.07.039

Tan, W. K. A., \& Sundarakani, B. (2020). Assessing +Blockchain Technology application for freight booking business: A case study from Technology Acceptance Model perspective. Journal of Global Operations and Strategic Sourcing, 14(1), 202-223. doi:10.1108/JGOSS-04-2020-0018

Tian, Z., Zhong, R. Y., Vatankhah Barenji, A., Wang, Y. T., Li, Z., \& Rong, Y. (2020). A blockchain-based evaluation approach for customer delivery satisfaction in sustainable urban logistics. International Journal of Production Research, 59(7), 1-21. doi:10.1080/00207543.2020.1809733

Tomlinson, B., Boberg, J., Cranefield, J., Johnstone, D., Luczak-Roesch, M., Patterson, D. J., \& Kapoor, S. (2020). Analyzing the sustainability of 28 "Blockchain for Good" projects via affordances and constraints. Information Technology for Development, 27(3), 1-31. doi:10.1080/02681102.2020. 1828792

Torraco, R. J. (2016). Writing integrative reviews of the literature: Methods and purposes. International Journal of Adult Vocational Education and Technology, 7(3), 62-70. doi:10.4018/IJAVET.2016070106

Toyoda, K., Machi, K., Ohtake, Y., \& Zhang, A. N. (2020). Function-level bottleneck analysis of private proof-of-authority Ethereum blockchain. IEEE Access, 8, 141611-141621. doi:10.1109/ACCESS.2020.3011876

Tsolakis, N., Niedenzu, D., Simonetto, M., Dora, M., \& Kumar, M. (2020). Supply network design to address United Nations Sustainable Development Goals: A case study of blockchain implementation in Thai fish industry. Journal of Business Research, 131, 1-25. doi:10.1016/j.jbusres.2020.08.003

Venkatesh, V. G., Kang, K., Wang, B., Zhong, R. Y., \& Zhang, A. (2020). System architecture for blockchain based transparency of supply chain social sustainability. Robotics and Computer-Integrated Manufacturing, 63, 101896. doi:10.1016/j.rcim.2019.101896 
Wang, B., Dabbaghjamanesh, M., Kavousi-Fard, A., \& Mehraeen, S. (2019). Cybersecurity enhancement of power trading within the networked microgrids based on blockchain and directed acyclic graph approach. IEEE Transactions on Industry Applications, 55(6), 7300-7309. doi:10.1109/TIA. 2019.2919820

Wang, S., Ouyang, L., Yuan, Y., Ni, X., Han, X., \& Wang, F. Y. (2019). Blockchain-enabled smart contracts: Architecture, applications, and future trends. IEEE Transactions on Systems, Man, and Cybernetics: Systems, 49(11), 2266-2277. doi:10.1109/TSMC.2019.2895123

Williams, C. C. (2005). Trust diffusion: The effect of interpersonal trust on structure, function, and organizational transparency. Business and Society, 44(3), 357-368. doi:10.1177/0007650305275299

Wong, L. W., Leong, L. Y., Hew, J. J., Tan, G. W. H., \& Ooi, K. B. (2020). Time to seize the digital evolution: Adoption of blockchain in operations and supply chain management among Malaysian SMEs. International Journal of Information Management, 52, 1-19. doi:10.1016/j.ijinfomgt.2019.08.005

Wu, J., \& Tran, N. K. (2018). Application of blockchain technology in sustainable energy systems: An overview. Sustainability, 10(9), 1-22. doi:10. 3390/su10093067

Yadav, S., \& Singh, S. P. (2020). An integrated fuzzy-ANP and fuzzy-ISM approach using blockchain for sustainable supply chain. Journal of Enterprise Information Management, 34(1), 54-78. doi:10.1108/JEIM-092019-0301

Yli-Huumo, J., Ko, D., Choi, S., Park, S., \& Smolander, K. (2016). Where is current research on blockchain technology? A systematic review. PLoS ONE, 11 (10), 1-28. doi:10.1371/journal.pone.0163477

Zhao, F., Guo, X., \& Chan, W. K. (2020). Individual green certificates on blockchain: A simulation approach. Sustainability, 12(9), 1-32. doi:10.33 90/su12093942

Zhao, G., Liu, S., Lopez, C., Lu, H., Elgueta, S., Chen, H., \& Boshkoska, B. M. (2019). Blockchain technology in agri-food value chain management: A synthesis of applications, challenges and future research directions. Computers in Industry, 109, 83-99. doi:10.1016/j.compind.2019.04.002 


\section{AUTHOR NOTES}

Hedwik D. Giesel, bachelor's degree from the Business School, Pontifical Catholic University of Paraná (PUCPR); Farley S. M. Nobre, Ph.D. from the Department of Industrial Engineering, University of Birmingham.

Hedwik D. Giesel is now a M.Sc. student at the School of Management of Federal University of Paraná (UFPR); Farley S. M. Nobre is now an associate professor at the School of Management of UFPR.

Correspondence concerning this article should be addressed to Farley S. M. Nobre, Avenida Prefeito Lothario Meissner, 632, Jardim Botânico, Curitiba, Paraná, Brazil, CEP 80210-170.

E-mail: f.nobre@ufpr.br or fsmnobre@gmail.com

\section{EDITORIAL BOARD}

Editor-in-chief

Gilberto Perez

Associate editor

Rodrigo Baroni de Carvalho

Technical support

Vitória Batista Santos Silva

\section{EDITORIAL PRODUCTION}

Publishing coordination

Jéssica Dametta

Language editor

Daniel de Almeida Leão

Layout designer

Emap

Graphic designer

Libro 